\title{
Lens Device
}

National Cancer Institute

\section{Source}

National Cancer Institute. Lens Device. NCI Thesaurus. Code C50030.

An electric or optical device designed to focus electromagnetic radiation. 